University of Nebraska - Lincoln

DigitalCommons@University of Nebraska - Lincoln

\title{
Impacts of air temperature variations on the boro rice phenology in Bangladesh: implications for irrigation requirements
}

\author{
Rezaul Mahmood \\ University of Nebraska-Lincoln, rmahmood2@unl.edu
}

Follow this and additional works at: https://digitalcommons.unl.edu/natrespapers

Part of the Natural Resources and Conservation Commons, Natural Resources Management and Policy Commons, and the Other Environmental Sciences Commons

Mahmood, Rezaul, "Impacts of air temperature variations on the boro rice phenology in Bangladesh: implications for irrigation requirements" (1997). Papers in Natural Resources. 1343.

https://digitalcommons.unl.edu/natrespapers/1343

This Article is brought to you for free and open access by the Natural Resources, School of at DigitalCommons@University of Nebraska - Lincoln. It has been accepted for inclusion in Papers in Natural Resources by an authorized administrator of DigitalCommons@University of Nebraska - Lincoln. 


\title{
Impacts of air temperature variations on the boro rice phenology in Bangladesh: Implications for irrigation requirements
}

\author{
Rezaul Mahmood \\ Department of Geography, College of Geosciences, University of Oklahoma, \\ Norman, OK 73019, USA \\ Correspondence (current address) - University of Nebraska-Lincoln, School of Natural \\ Resources, email rmahmood2@unl.edu \\ ORCID https://orcid.org/00oo-0002-1849-7970
}

\begin{abstract}
Air temperature significantly affects crop phenology. Numerous experiments have shown that prevailing air temperature determines the length of crop growth stages. Irrigation field requirements depend on the length of the crop growth stages. In the present study, a physically based parametric model, YIELD, has been applied to estimate the impacts of fluctuating air temperature (due to inter-annual climatic variability and global warming) on evapotranspiration water requirements and the length of growth stages of the irrigated boro rice in Bangladesh. The YIELD model is crop specific and crop-growth-stage specific which is a compromise between areaspecific regression models and complex crop growth simulation models. The model was tuned to Bangladesh's environment to represent appropriate agro-ecological conditions including soil type, depth of ground water, field size, wind regime, and percolation losses. YIELD has been validated for the length of the growth stages, length of growing season, final yield, and evapotranspiration. A baseline estimate
\end{abstract}

Published in Agricultural and Forest Meteorology 84:3-4 (April 1997), pp 233-247.

DOI:10.1016/So168-1923(96)02360-X

Copyright (C) 1997 Elsevier Science B.V. Used by permission.

Submitted 28 July 1995; accepted 29 April 1996. 
for the boro rice phenology has been established by running the model for 12 meteorological stations located in the major rice growing regions. Based on the analysis of the past variations of air temperature and general circulation model (GCM) predictions, ten scenarios have been created to estimate the effects of these variations on the boro rice growth stages. These applications find that the planting date plays an important role in the boro rice phenology. This effect is most noticeable during initial growth stages. This study has found a non-linear relationship between decreasing air temperature and the length of the initial growth stage and a predominantly linear relationship with other growth stages. Model applications show that an increase in air temperature will provide longer and more stable thermal conditions for boro rice maturing stage. A $5 \%$ increase and a $4 \%$ decrease in seasonal total evapotranspiration will occur under each $1^{\circ}$ cooler and warmer air temperature conditions, respectively. A rise in evapotranspiration will cause higher demands for irrigation water. Such conditions will put pressure on the current irrigation infra-structural facilities in Bangladesh and result in reduction of boro yields. Furthermore, variations in the percent of time required for the completion of different growth stages under various air temperature conditions will demand a reorganization of irrigation schedules.

Keywords: Air temperature variations; Boro rice phenology; Irrigation requirements

\section{Introduction}

Numerous studies have shown that temperature plays an important role in rice plant physiology and growth (Munakata, 1976; Nishiyama, 1976; De Datta, 1981; Yoshida, 1981; Haque, 1986; Oldeman et al., 1987). Air temperature variations influence germination (Yoshida, 1981, Yoshida, 1983), seedling growth (Yoshida, 1981), and vegetative and reproductive growth (Munakata, 1976; Nishiyama, 1976). Haque (1987), Oldeman et al. (1987), and Yoshida (1983) noted that higher and lower air temperatures reduce and extend lengths of rice plant growth stages, respectively, and influence the length of the total growing season. Thus, inter- and intra-annual temperature fluctuations can affect the rice plant's physiology and related growth parameters. In addition to these temperature fluctuations, $2 \times \mathrm{CO}_{2}$ induced global temperature increases are a major threat to world-wide agricultural practices (Parry et al., 1985; Parry and Carter, 1990; Parry, 1992; Rosenzweig and Hillel, 1993; Rosenzweig and Parry, 1994). In a previous paper, Mahmood and Hayes (1995) presented the possible impacts of abnormal thermal and solar climate on the winter season boro rice yield, the length of the boro rice growing season, 
and several other growth related parameters. This study assesses the impacts of cooler or warmer temperature on the length of the individual growth stages of boro rice in Bangladesh. Additionally, the impacts of these abnormal thermal conditions on the irrigation requirements have been investigated. A crop growth simulation model, YIELD (Hayes et al., 1982a, Hayes et al., 1982b) has been applied to ten synthetically fluctuated air temperature scenarios to assess impacts of abnormal thermal conditions on the length of growth stages and irrigation requirements. The YIELD model is able to simulate and predict seasonal crop yield and growth parameters for 11 crops including rice. A set of 12 meteorological stations, well distributed over the major rice growing regions in Bangladesh, have been selected and used in this study (Fig. 1). Furthermore, these stations are consolidated into three groups based on their latitudinal locations.

\section{The rice growing; seasons and irrigation facilities in Bangladesh}

Favorable hydroclimatic conditions allow Bangladeshi farmers to grow rice year round. The three major rice crops are boro, aus, and aman. The growing season for boro, aus, and aman starts and ends during the months of December and May, March and August, and June and November, respectively. These growing seasons nearly synchronize with the three climatic seasons namely, winter (November through February), the hot summer (March through May), and the monsoon (June through October). Table 1 presents climatic features of the three rice growing seasons.

Bangladesh Rice Research Institute (BRRI) reported that $85 \%$ of the boro rice varieties cultivated in Bangladesh are irrigated modern varieties (BRRI, 1991). Since boro rice grows during the dry winter and the hot summer season its water requirements are fulfilled by irrigation. Aus rice requires supplemental irrigation during the first part of its growing season while aman is a rain-fed rice that grows during monsoon months.

Due to improvements in irrigation facilities over the last few decades, the share of boro rice production in Bangladesh has increased from $5 \%$ of the total production in the early 1960 s to $20 \%$ in the 


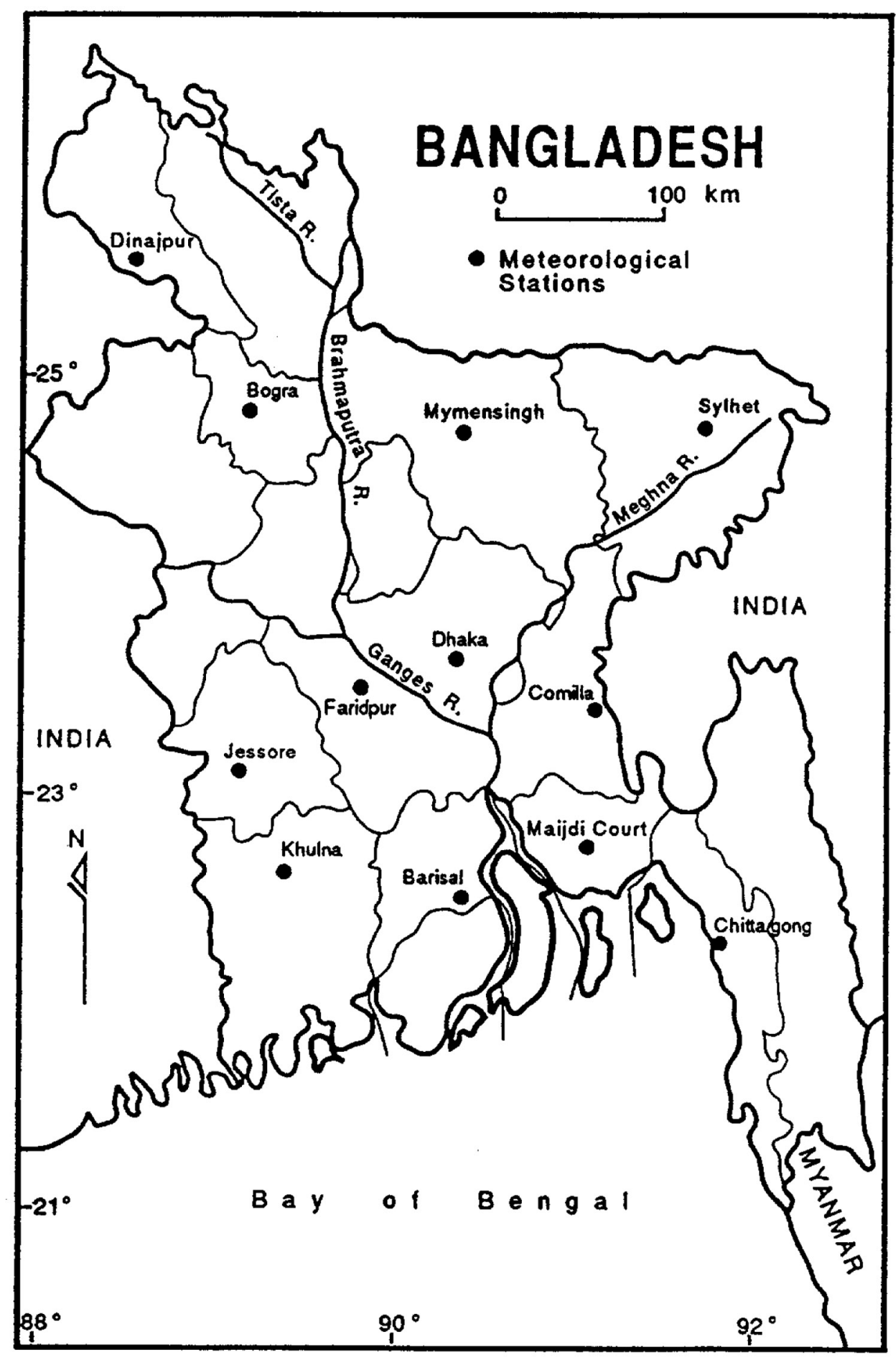

Fig. 1. Location of meteorological stations in Bangladesh. 
Table 1 Important features of climate of Bangladesh during the three rice growing seasons

\begin{tabular}{lllll} 
Rice cropping seasons & $T_{\max }\left({ }^{\circ} \mathrm{C}\right)$ & $T_{\min }\left({ }^{\circ} \mathrm{C}\right)$ & $Q\left(M J \mathrm{~m}^{-2}\right.$ day $\left.^{-1}\right)$ & Precipitation $(\mathrm{mm})$ \\
\hline Aus (Mar-Aug) & $34-31$ & $16-26$ & $14-23$ & $1200-3100$ \\
Aman (June-Nov) & $34-28$ & $26-16$ & $14-19$ & $1250-3000$ \\
Boro (Dec-May) & $24-34$ & $10-26$ & $14-23$ & $250-550$ \\
\hline
\end{tabular}

$\mathrm{T}_{\max }$, mean maximum air temperature; $\mathrm{T}_{\min }$, mean minimum air temperature; $\mathrm{Q}$, solar radiation.

Ascending and descending values for $\mathrm{T}_{\max }, \mathrm{T}_{\min }$, and $\mathrm{Q}$ represent respective increase and decrease as rice growing season progresses.

Precipitation shows seasonal total with regional variation.

mid-1970s and 26\% during the mid-1980s (BRRI, 1988). During 197677 cropping season, 1,216,000 ha of agricultural lands were provided with irrigation water by using both modern and traditional methods. In 1980-81 1,639,000 ha of agricultural lands were supplied with irrigation water while in 1984-85 the area irrigated increased to 2,074, ooo ha (Choudhuri, 1988). Moreover, improvements in irrigation facilities have reduced the boro rice's dependence on rain and largely eliminated the effects of deficient rainfall. These conditions have encouraged local authorities to emphasize an increase in boro rice cultivation and have further influenced the expansion of irrigation facilities.

\section{The YIELD model}

The YIELD model evolved from a crop water balance model called WATER developed by Burt et al. (1980), Burt et al. (1981). It has been validated for several major agricultural crops including rice, grain com, wheat, barley, potato, and alfalfa (Burt et al., 1980, Burt et al., 1981; Mearns, 1982; Hayes et al., 1982a, Hayes et al., 1982b). YIELD model has been successfully applied to several regional studies including Australia (Mearns, 1982), China (Terjung et al., 1983, Terjung et al., 1984a, Terjung et al., 1984b, Terjung et al., 1984c, Terjung et al., 1984d, Terjung et al., 1984e, Terjung et al., 1984f, Terjung et al., 1985, Terjung et al., 1989; Todhunter et al., 1989), the North American Great Plains (Terjung et al., 1984g; Liverman et al., 1986), 
California (Hayes, 1986), and Bangladesh (Mahmood, 1993; Mahmood and Hayes, 1995).

The YIELD model's evapotranspiration calculation is based upon methods developed by Doorenbos and Pruitt (1977) and Doorenbos and Kassam (1979). They have used the Penman (1948) equation to calculate evapotranspiration (ET). Penman's equation combines energy balance and aerodynamic functions to calculate evapotranspiration. Doorenbos and Pruitt (1977) successfully modified this equation for reference crops (which is an extended surface of 8 to $15 \mathrm{~cm}$ tall, green grass cover of uniform height, actively growing, completely shading the ground and not short of water). The modified equation included the effects of crop type, crop-growth-stage, selected site factors, influence of unusual climatic conditions, ET adjusting crop coefficients ET for specific crops and specific crop growth stages, and soil moisture budget conditions. The submodels CROP1, 2, 3, 4, and 5 constitute the calculation procedure for ET of the reference crop and actual crop (Table 2). The model calculates each variable for a set time step. In this study time step is 5 days. ET is the sum of radiative and moisture terms, involving net radiation and atmospheric vapor pressure deficit, respectively, in CROP1 (Doorenbos and Pruitt, 1977; Burt et al., 1980). CROP2 adjusts CROP1 for wind regimes, radiation amounts, and mean daily maximum relative humidity. $\mathrm{CROP}_{3}$ is the adjustment for CROP2 by crop-specific, growth-stage-specific coefficients which consider varying effects of crop growth stages on plant water use. CROP4 adjusts CROP3 for 'clothesline' and 'oasis' effects. Optimal water conditions have been assumed up to CROP4. CROP5 deals with an array of possible water stress situations of a specific crop and specific growth stages. For each crop and season, a soil water budget is calculated. In the YIELD model, soil water budgets are a function of a number of variables that includes growth-stage-specific ET, soil water storage, effective precipitation, groundwater contributions, variable root depths, and percolation losses. As this study assumes optimum supply of water, $\mathrm{CROP}_{5}$ is equal to $\mathrm{CROP}_{4}$. Further description of the YIELD model can be found in Burt et al. (1980) and Hayes et al. (1982b). 
Table 2 Summary of ET related equations used in the YIELD model

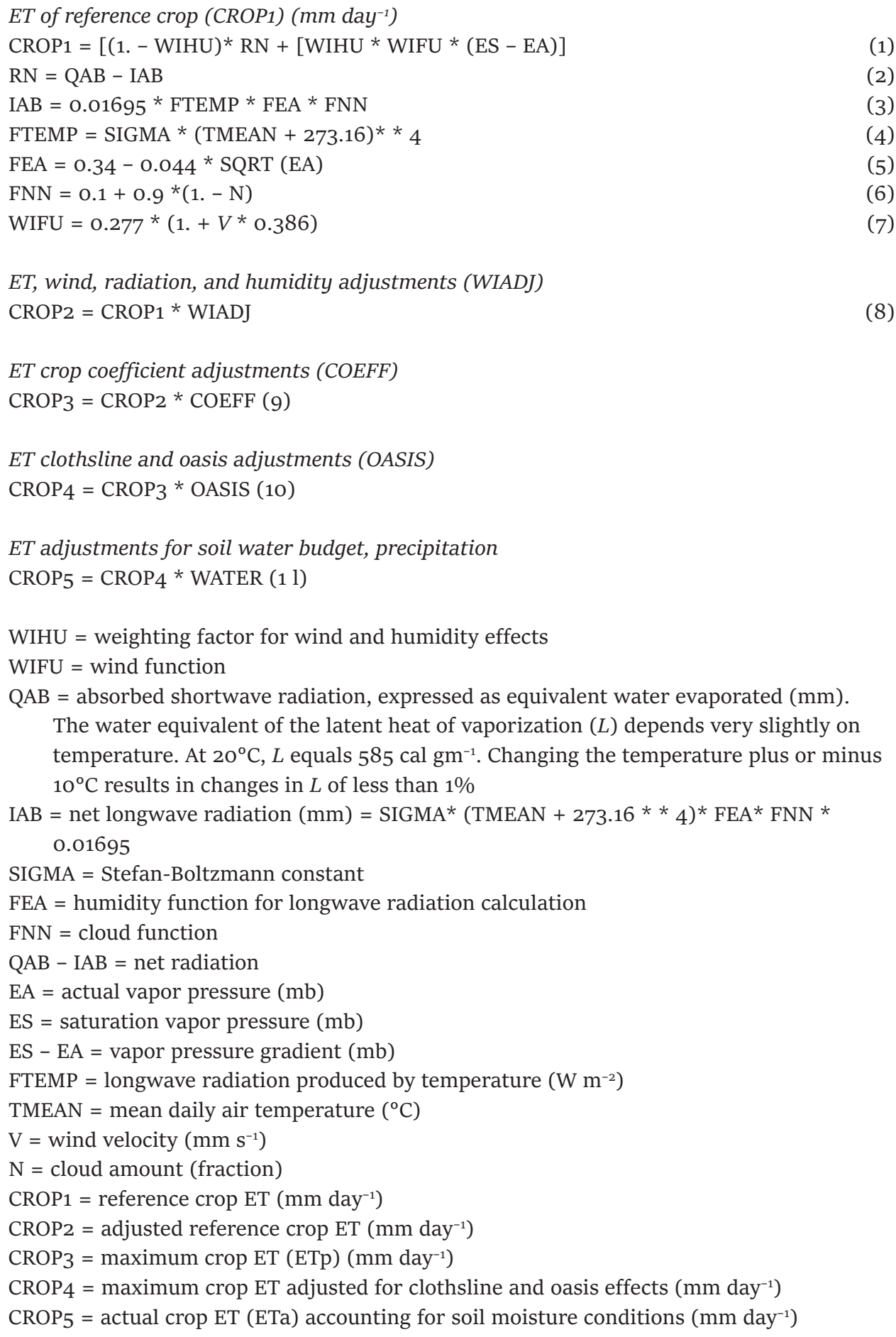

Source: Hayes (1986). 


\section{Input data and validation of the YIELD model for Bangladesh application}

Long-term (1950-80) monthly average climate data of the 12 meteorological stations in Bangladesh have been used as model input in this study (Fig. 1). Mean monthly maximum and minimum air temperatures, mean monthly daily solar radiation, mean monthly wind speed, and precipitation data were obtained from the Food and Agricultural Organization of the United Nations (FAO, 1987). Mean monthly cloud cover and maximum and minimum relative humidity data were computed from the Bangladesh Meteorological Department's (BMD's) daily data (1975-1990). Data for monthly precipitation days of Sylhet, Bogra, Dhaka, Jessore, and Chittagong were obtained from Rudolff (1981) while that of the other stations were calculated from the BMD's daily data. The rice agronomy input data required for the model run is presented in Table 3.

\subsection{Validation of the phenology submodel}

The YIELD model adopts a phenology submodel partially developed from Doorenbos and Pruitt (1977). Burt et al. (1980) presented a detailed description of this procedure. The submodel is based upon the concept of cumulative degree days above a crop-specific threshold temperature which is a function of latitude. In other words, the accumulation of a certain amount of degree days of heat marks the end of a growth stage. In this study, a base temperature of $15^{\circ} \mathrm{C}$ (BRRI, 1991) has been used for these calculations (Table 3). The YIELD model has been applied to 1987 and 1988 data at BRRI's experiment station

Table 3 Agronomic data inputs for calibration of the YIELD model

\begin{tabular}{lll} 
Model parameter & Value assigned & Source \\
\hline Slope of the field & Flat & Mahmood (1993) \\
Soil type & Loamy & Mahmood (1993) \\
Root depth & Initial: 0.15 m; maximum: O.50 m & Yoshida (1981) \\
Percolation loss rate & $4 \mathrm{~mm} \mathrm{day}^{-1}$ & BRRI (1991) \\
Harvest index & 0.49 & Biswas et al. (1989) \\
Base temperature & $15^{\circ} \mathrm{C}$ & BRRI (1991) \\
Transplanting date & January 1 $^{\circ}$ & Mahmood (1993) \\
Day/night wind ratio & $2: 1$ & Mahmood (1993) \\
\hline
\end{tabular}


Table 4 Phenology submodel validation for Dhaka, Bangladesh

\begin{tabular}{lllll} 
Growth stages (in days) & $\begin{array}{l}\text { Doorenbos } \\
\text { and Pruitt } \\
\text { (1977) }\end{array}$ & $\begin{array}{l}\text { Doorenbos } \\
\text { and Kassam } \\
\text { (1979) }\end{array}$ & $\begin{array}{l}\text { Model run } \\
\text { for 1987 }\end{array}$ & $\begin{array}{l}\text { Model run } \\
\text { for 1988 }\end{array}$ \\
\hline Initial stage (1) & 20 & 10 & 10 & 10 \\
Vegetative stage (2) & 35 & $40-60$ & 60 & 60 \\
Flowering/heading stage (3) & 40 & $10-15$ & 40 & 35 \\
Maturing stage (4) & 30 & $35-55$ & 20 & 25 \\
\hline
\end{tabular}

at Gazipur, Dhaka to evaluate its performance. The model-estimated number of days required to accumulate the heat to complete each growth stage have been compared to the rice phenology proposed by Doorenbos and Pruitt (1977) and Doorenbos and Kassam (1979) and validated (Table 4). The differences between the Doorenbos and Pruitt (1977) and Doorenbos and Kassam (1979) proposed lengths of various growth stages and the YIELD model calculated length of growth stages result from the nature of local climate and the cultivar. Tables 5 and 6 present YIELD model-estimated cumulative degree days for each growth stage, and the length of each of the growth stage, respectively, for each station under 'normal' climatic conditions.

Table 5 Accumulated heat $\left({ }^{\circ} \mathrm{C}\right)$ at the end of the growth Stages $1,2,3$, and 4

\begin{tabular}{lcccc} 
Stations & $\begin{array}{l}\text { Initial } \\
\text { stage (1) }\end{array}$ & $\begin{array}{l}\text { Vegetative } \\
\text { stage (2) }\end{array}$ & $\begin{array}{l}\text { Flowering/heading } \\
\text { stage (3) }\end{array}$ & $\begin{array}{l}\text { Maturing } \\
\text { stage (4) }\end{array}$ \\
\hline $\begin{array}{l}\text { Northern region } \\
\text { Sylhet }\end{array}$ & 80.00 & 528.00 & 1051.00 & 1290.00 \\
Bogra & 80.00 & 528.00 & 1052.00 & 1291.00 \\
Mymensingh & 80.00 & 530.00 & 1055.00 & 1294.00 \\
Dinajpur & 80.00 & 515.00 & 1032.00 & 1273.00 \\
Central region & & & & 1311.00 \\
Dhaka & 79.00 & 540.00 & 1071.00 & 1318.00 \\
Faridpur & 78.00 & 544.00 & 1078.00 & 1323.00 \\
Comilla & 78.00 & 546.00 & 1082.00 & 1328.00 \\
Jessore & 78.00 & 549.00 & 1087.00 & 1369,00 \\
Southern region (with pronounced & coastal influence) & & 1337.00 \\
Chittagong & 76.00 & 571.00 & 1126.00 & 1338.00 \\
Khulna & 78.00 & 554.00 & 1096.00 & 1335.00 \\
Barisal & 77.00 & 554.00 & 1096.00 & 1094.00 \\
Maijdi Court & 78.00 & 553.00 & & \\
\hline
\end{tabular}


Table 6 Length of the individual growth stages (in days) for boro rice under normal climate

\begin{tabular}{lclll} 
Stations & $\begin{array}{l}\text { Initial } \\
\text { stage (1) }\end{array}$ & $\begin{array}{l}\text { Vegetative } \\
\text { stage (2) }\end{array}$ & $\begin{array}{l}\text { Flowering/heading } \\
\text { stage (3) }\end{array}$ & $\begin{array}{l}\text { Maturing } \\
\text { stage (4) }\end{array}$ \\
\hline $\begin{array}{l}\text { Northern region } \\
\text { Sylhet }\end{array}$ & 20 & 65 & 45 & 25 \\
Bogra & 25 & 60 & 40 & 20 \\
Mymensingh & 20 & 60 & 45 & 20 \\
Dinajpur & 25 & 60 & 40 & 20 \\
Central region & & & & \\
Dhaka & 15 & 65 & 40 & 20 \\
Faridpur & 20 & 65 & 40 & 20 \\
Comilla & 15 & 60 & 45 & 20 \\
Jessore & 15 & 60 & 40 & 20 \\
Southern region & (with pronounced coastal influence) & & \\
Chittagong & 15 & 65 & 45 & 20 \\
Khulna & 10 & 60 & 40 & 20 \\
Barisal & 15 & 60 & 40 & 25 \\
Maijdi Court & 10 & 65 & 40 & \\
\hline
\end{tabular}

\subsection{Validation of the ET submodel}

Due to lack of published lysimeter and other consumptive use data it was very difficult to validate rice ET for Bangladesh. However, this study finds that BRRI recorded a total $741 \mathrm{~mm}$ ET for the 114 day long boro rice growing season during an experiment at the Dhaka station in 1982 (Fig. 2(a)) (BRRI, 1985). The YIELD model estimated 710 rom total growing season ET (140 day) at Dhaka, under normal climate conditions (Fig. 2(b)). The higher seasonal total ET in 1982 was most probably a result of higher mean maximum daily air temperatures during the boro rice growing season (BRRI, 1985). The shorter growing season indicates toward the higher mean maximum growing season air temperature in 1982. Additionally, the higher seasonal total ET in 1982 and the relatively shorter growing season results in higher ET rates $\left(6 \mathrm{~mm} \mathrm{day}^{-1}\right)$ compared with the model-predicted value (5 mm day ${ }^{-1}$ ) under standard climatic conditions. Thus, it appears that model estimation of ET is satisfactory. Mahmood (1993) and Mahmood and Hayes (1995) provided a detailed description of tuning and validation of the model. 

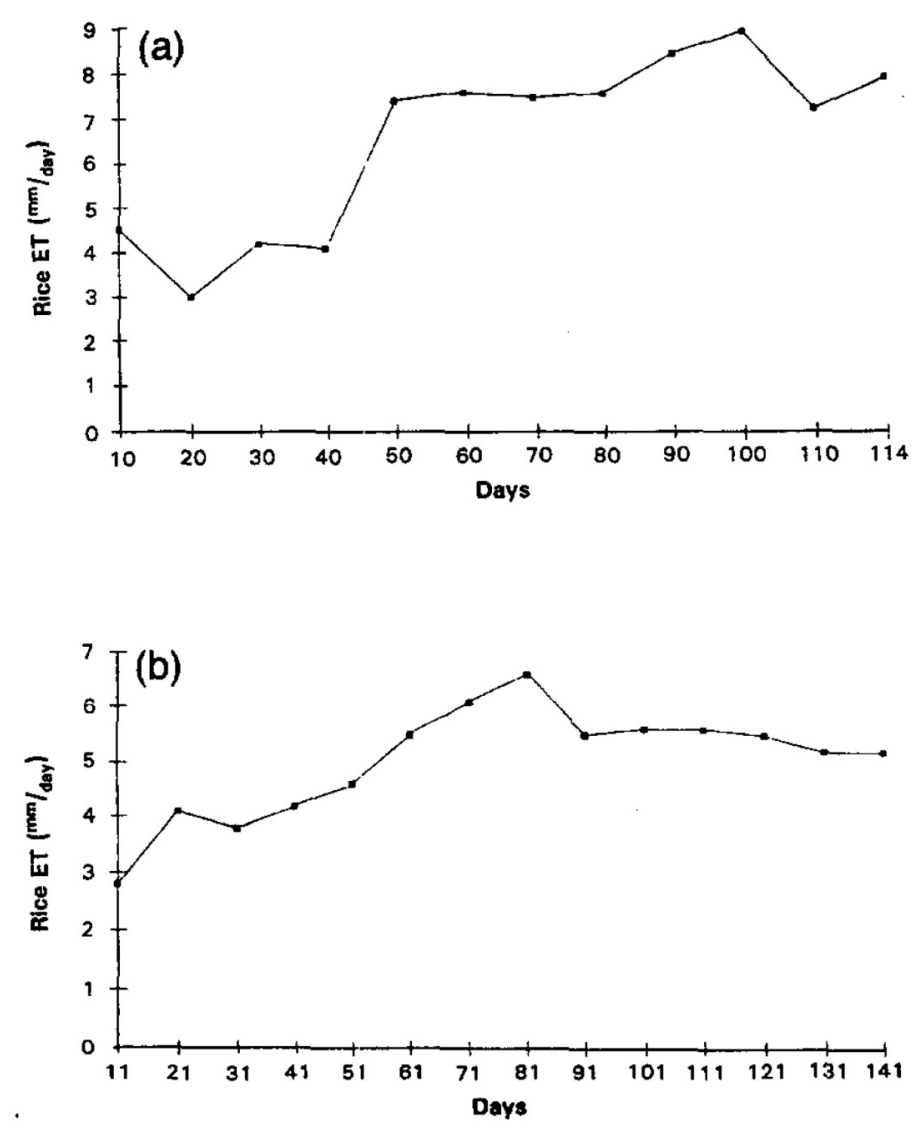

Fig. 2. (a) Daily ET measured at Dhaka in 1982. (b) The model estimated ET for Dhaka.

\section{Thermal climate variability in Bangladesh}

Mahmood and Hayes (1995) conducted a survey of monthly mean maximum and minimum and daily maximum and minimum air temperature for the boro rice growing season (January through May) for centrally located Dhaka from 1975 through 1990. It shows that the monthly mean maximum air temperatures deviate by up to $4^{\circ} \mathrm{C}$ and daily maximum temperatures deviate by up to $7^{\circ} \mathrm{C}$ from the long term monthly mean. It was found that monthly mean minimum and daily minimum temperatures fluctuated up to $2^{\circ} \mathrm{C}$ and up to $6^{\circ} \mathrm{C}$, respectively, from the normal.

In recent years, advanced general circulation models (GCMs) have been applied to estimate the effects and extent of global warming over various regions of the world under $2 \times \mathrm{CO}_{2}$ conditions. The Canadian 
Climate Center (CCC), the Geophysical Fluid Dynamics Laboratory (GFDL), and the United Kingdom Meteorological Office (UKMO) GCMs estimate a 2 to 4,4 to 6 , and 2 to $4^{\circ} \mathrm{C}$ increase of the winter season air temperature in Bangladesh, respectively (Mitchell et al., 1990). These models also suggest that precipitation would decrease by 1 to $2 \mathrm{~mm}$ day $^{-1}$ during the winter season. Zhao and Kellogg (1988) performed a comparative study on the performance of five GCMs, namely, the GFDL, the UKMO, the National Center for Atmospheric Research (NCAR), the Oregon State University (OSU), and the Goddard Institute for Space Studies (GISS), regarding the potential sensitivity of soil moisture to $2 \times \mathrm{CO}_{2}$ conditions in the Asian monsoon region. All five GCMs predicted a decrease in soil moisture during the winter season in Bangladesh.

It is important to note that there are significant amount of uncertainties involved in these model predictions. The causes of these uncertainties are inherent in the structure of the model, model assumptions, and model physics. Ghan (1992) noted that size of the GCM grid cell is too large to capture many relatively smaller scale processes correctly. Increasing inaccuracy associated with the GCMs treatment of smaller scale advection and mixing are contributing in the uncertainty of the model predictions (Ghan, 1992). Furthermore, Dickinson (1989) suggested that the GCMs physics have been limited by our current insufficient knowledge of the various planetary processes. As a result, in many cases these processes and the related assumptions are unrealistic and oversimplified. Some of these poorly treated processes include transient adjustment controlled by ocean heat uptake, changes in the cloud cover and their radiative effect, changes in cloud optical properties, changes in atmospheric stability and moisture distribution, changes in sea-ice cover and their radiative effect, and surface hydrological responses.

Despite these uncertainties of the GCM predictions, the importance of their prognostications still contain significant value for the impact studies (Ghan, 1992). As such, based on the past records of variations in thermal climate of Bangladesh and the GCM predictions, ten scenarios have been created by deviating the mean air temperature $\left(T_{\text {air }}\right)$ up to $\pm 5^{\circ} \mathrm{C}$ with a $1^{\circ} \mathrm{C}$ interval. These scenarios have been applied to all 12 meteorological stations in Bangladesh to estimate the impacts of the variations in regional thermal climatic conditions on boro rice growing season and irrigation requirements. 

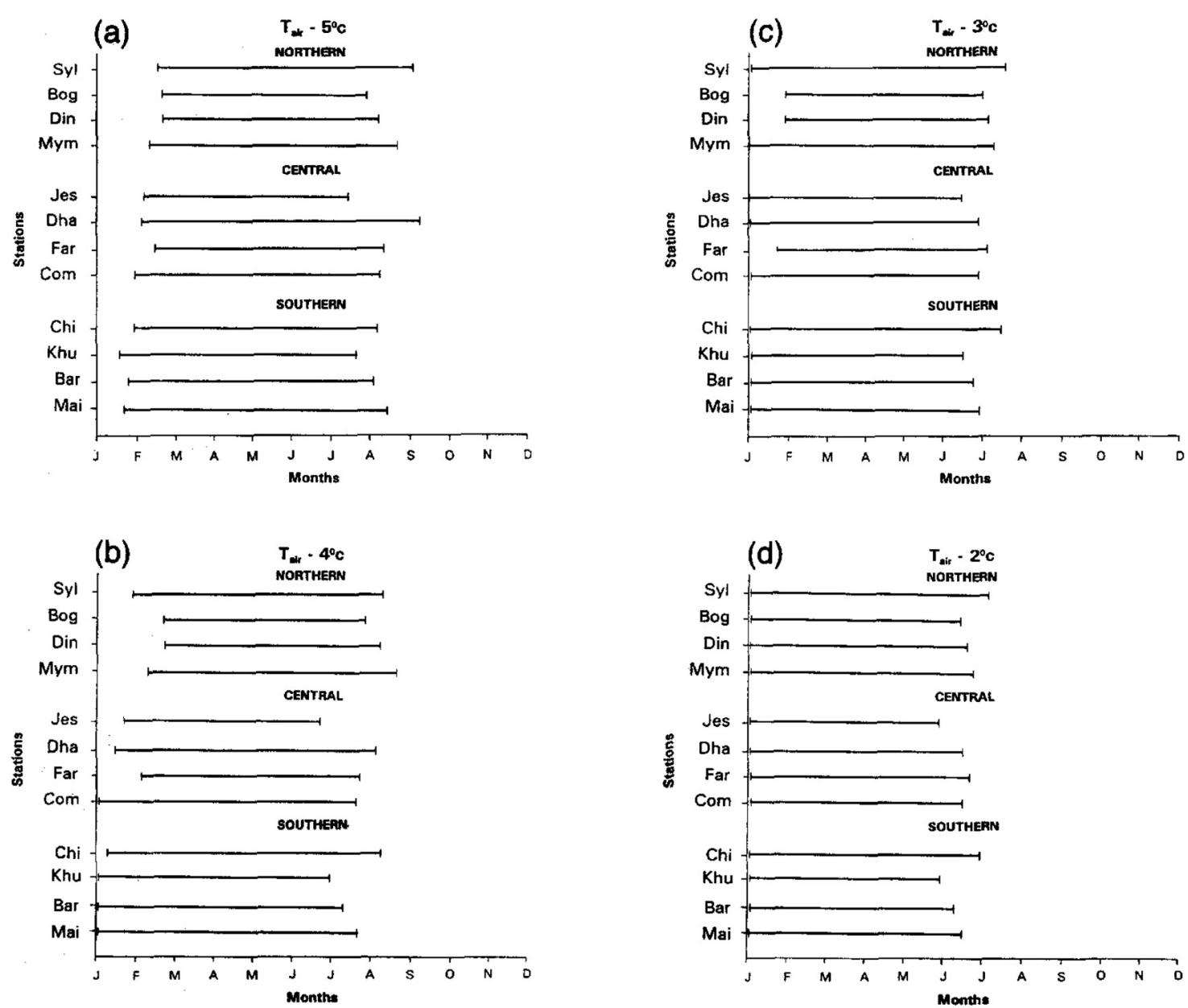

Fig. 3. The length of growing seasons over the northern, central, and southern region of Bangladesh under below normal thermal conditions.

\section{Results and discussions}

\subsection{Effect of abnormal air temperature on the length of growing season}

Fig. 3(a)-(d) presents transplanting and harvesting dates under reduced temperatures (below normal). Under the mean $T_{\text {air }}-5,-4$, and $-3^{\circ} \mathrm{C}$ scenarios, transplanting dates have been pushed from the originally specified date of January 1 to later dates to avoid possible frost. This study finds that under mean $T_{\text {air }}-5$ and $-4^{\circ} \mathrm{C}$ conditions, cooler northerly areas (e.g. Dinajpur, Bogra, and Sylhet) experience up to 7 
Table 7 Length of the boro rice growing season (number of days to reach maturity) in Bangladesh under standard, reduced, and increased mean $\mathrm{T}_{\text {air }}$ scenarios

\begin{tabular}{lcccccc} 
Station & Normal climate & $-5^{\circ} \mathrm{C}$ & $-4^{\circ} \mathrm{C}$ & $-3{ }^{\circ} \mathrm{C}$ & $-2^{\circ} \mathrm{C}$ & $-1^{\circ} \mathrm{C}$ \\
\hline Northern region & & & & & & \\
$\quad$ Sylhet & 155 & 200 & 190 & 200 & 185 & 170 \\
Bogra & 145 & 160 & 155 & 150 & 165 & 155 \\
Mymensingh & 145 & 190 & 180 & 190 & 175 & 160 \\
Dinajpur & 145 & 170 & 165 & 155 & 170 & 160 \\
Central region & & & & & \\
Dhaka & 140 & 185 & 190 & 180 & 165 & 150 \\
Faridpur & 145 & 180 & 170 & 165 & 170 & 155 \\
Comilla & 140 & 190 & 200 & 180 & 165 & 150 \\
Jessore & 135 & 160 & 155 & 165 & 150 & 140 \\
Southern region (with & pronounced coastal & influence) & & & & \\
Chittagong & 150 & 220 & 210 & 195 & 180 & 165 \\
Khulna & 130 & 180 & 180 & 165 & 150 & 140 \\
Barisal & 135 & 190 & 190 & 175 & 160 & 145 \\
Majdi Court & 140 & 205 & 200 & 180 & 165 & 150 \\
\hline
\end{tabular}

weeks of late transplanting as compared with the Chittagong region which experiences up to 4 weeks of late transplanting due to relatively moderate coastal climate. Centrally located Dhaka has a transplanting date that lies between those of the northern and southern regions. Table 7 presents the model predicted length of boro rice growing seasons for the 12 meteorological stations under cooler thermal conditions. It is evident that in most cases, the length of the growing season increases with decreasing air temperature as there is a longer time requirements for the accumulation of heat to complete physiological cycles. Few exceptions to this trend occur due to the changes in transplanting date as a result of cooler thermal conditions. For example, in the case of Dinajpur the length of growing season decreases with increasing air temperature until $T_{\text {air }}-3^{\circ} \mathrm{C}$ condition. Under $T_{\text {air }}$ $-2^{\circ} \mathrm{C}$ condition, the length of boro rice growing season increases and equals the $T_{\text {air }}-5^{\circ} \mathrm{C}$ scenario. Due to the relatively less cool thermal climate, the model forces the transplanting date back to January 1 in Dinajpur. Although the transplanting date is back to the normal date, the growing season temperature is still cooler than normal conditions. This forces the rice plants to grow under cooler conditions for a longer period of time. As noted previously, this condition requires longer 
Table 8 Length of initial growth stage (in days) under below normal thermal conditions

\begin{tabular}{lcccccc} 
Station & Standard climate & $-5^{\circ} \mathrm{C}$ & $-4^{\circ} \mathrm{C}$ & $-3^{\circ} \mathrm{C}$ & $-2^{\circ} \mathrm{C}$ & $-1^{\circ} \mathrm{C}$ \\
\hline $\begin{array}{l}\text { Northern region } \\
\text { Sylhet }\end{array}$ & 20 & 25 & 35 & 50 & 35 & 25 \\
Bogra & 25 & 20 & 25 & 25 & 50 & 35 \\
Mymensingh & 20 & 25 & 30 & 50 & 35 & 25 \\
Dinajpur & 25 & 20 & 25 & 30 & 50 & 35 \\
Central region & & & & & & \\
Dhaka & 15 & 25 & 35 & 40 & 30 & 20 \\
Faridpur & 20 & 20 & 25 & 30 & 40 & 30 \\
Comilla & 15 & 30 & 50 & 40 & 30 & 20 \\
Jessore & 15 & 25 & 30 & 40 & 30 & 20 \\
Southern region (with pronounced coastal influence) & & & & \\
$\quad$ Chittagong & 15 & 30 & 40 & 40 & 25 & 20 \\
Khulna & 10 & 35 & 40 & 30 & 20 & 15 \\
Barisal & 15 & 30 & 45 & 35 & 25 & 20 \\
Maijdi Court & 10 & 35 & 45 & 35 & 25 & 15 \\
\hline
\end{tabular}

time period to accomplish plant physiological processes in Dinajpur, which results in longer growing season under $T_{\text {air }}-2^{\circ} \mathrm{C}$ scenario compared with $T_{\text {air }}-4$ and $-3^{\circ} \mathrm{C}$ scenarios. Under $T_{\text {air }}-4$ and $-3^{\circ} \mathrm{C}$ scenarios transplanting dates, are relatively closer to the warm season which causes a faster accumulation heat during the vegetative and flowering/heading stages and an overall shorter growing season in Dinajur. Furthermore, warmer (above normal) air temperatures have resulted in a shorter than normal growing season for all the 12 stations due to faster accumulation of growing season heat. The following section of this paper will expand on the effects and impacts that cooler conditions have on individual growth stages and total growing season.

\subsection{Effects of temperature variation on the length of boro rice} growth stages

Table 8 presents the lengths of initial crop growth stage under below normal air temperature scenarios. The results presented in this table show that the lengths of the initial growth stage are shorter under mean $T_{\text {air }}-5^{\circ} \mathrm{C}$ condition as compared with the mean $T_{\text {air }}-4$, $-3,-2$, and $-1^{\circ} \mathrm{C}$ scenarios. It has already been recorded that due to 
cooler than normal air temperature the YIELD model pushed transplanting dates 2 to 7 weeks forward under $T_{\text {air }}-5^{\circ} \mathrm{C}$ scenario (Fig. $3(\mathrm{a})$ ). It has also been shown that this accelerates boro rice plant's entrance to the hot summer season within a short period of time. Furthermore, cooler than normal air temperatures also lead to a faster accumulation of heat and a quicker completion of the initial growth stage. Under $-4^{\circ} \mathrm{C}$ scenario, for all of the rice growing regions, the model moves the transplanting dates close to January 1 due to relatively less cool air temperatures. The $T_{\text {air }}-4^{\circ} \mathrm{C}$ forces rice plants to grow under cooler conditions after transplanting during its initial growth stage. However, such thermal conditions require longer period of time to accumulate heat to complete the growth stage. In other words, $T_{\text {air }}-4^{\circ} \mathrm{C}$ scenario produces a longer initial growth stage than the $T_{\text {air }}-5^{\circ} \mathrm{C}$ scenario. The length of the initial growth stage also increases over the most of the rice growing regions under the mean $T_{\text {air }}-3^{\circ} \mathrm{C}$ scenario. In the case of Khulna, Barisal, and Maijdi Court, the length of the initial growth stage starts decreasing from $T_{\text {air }}-3^{\circ} \mathrm{C}$ scenario. This probably occurs because of pronounced coastal climatic effects. The length of the initial growth stage continues to increase in Bogra and Dinajpur up to mean $T_{\text {air }}-2^{\circ} \mathrm{C}$ scenario due to cooler air temperatures (Table 8). Under the mean $T_{\text {air }}-2^{\circ} \mathrm{C}$ scenario transplanting dates at Bogra and Dinajpur are set to January 1 due to comparatively higher air temperatures. Although temperatures increase in Bogra and Dinajpur, in general they are still low compared with other regions. The combination of cooler northerly locations and lower air temperatures resulted in longer initial growth stage in Bogra and Dinajpur compared with others under the mean $T_{\text {air }}-2^{\circ} \mathrm{C}$ conditions. In the mean time, lengths of vegetative, flowering/heading, and maturing stages continue to decrease with increasing air temperatures. Hence., the initial growth stage does not show a linear relationship with decreasing air temperature. As already shown, the YIELD model calculated transplanting dates play an important role in this non-linear relationship.

Under above normal air temperature conditions, the length of the boro rice growing season and the lengths of individual growth stages (except for the maturing stage) decrease steadily. The model estimates minor changes in the length of the maturing stage under increased air temperature conditions (Table 9). Model calculated shortening of the 
Table 9 Length of maturing stage (in days) under above normal thermal conditions

\begin{tabular}{|c|c|c|c|c|c|c|}
\hline Station & Standard climate & $+1^{\circ} \mathrm{C}$ & $+2{ }^{\circ} \mathrm{C}$ & $+3^{\circ} \mathrm{C}$ & $+4^{\circ} \mathrm{C}$ & $+5^{\circ} \mathrm{C}$ \\
\hline \multicolumn{7}{|l|}{ Northern region } \\
\hline Sylhet & 25 & 25 & 25 & 20 & 25 & 20 \\
\hline Bogra & 20 & 20 & 20 & 20 & 20 & 20 \\
\hline Mymensingh & 20 & 20 & 20 & 20 & 20 & 20 \\
\hline Dinajpur & 20 & 25 & 20 & 20 & 25 & 25 \\
\hline \multicolumn{7}{|l|}{ Central region } \\
\hline Dhaka & 20 & 20 & 20 & 25 & 25 & 20 \\
\hline Faridpur 2020 & 20 & 25 & 25 & 25 & & \\
\hline Comilla & 20 & 20 & 25 & 25 & 25 & 25 \\
\hline Jessore & 20 & 25 & 25 & 25 & 25 & 20 \\
\hline \multicolumn{7}{|c|}{ Southern region (with pronounced coastal influence) } \\
\hline Chittagong & 25 & 20 & 20 & 25 & 25 & 25 \\
\hline Khulna & 20 & 20 & 20 & 20 & 20 & 20 \\
\hline Barisal & 20 & 25 & 20 & 20 & 20 & 20 \\
\hline Maijdi Court & 25 & 20 & 25 & 20 & 20 & 25 \\
\hline
\end{tabular}

length of the boro rice growing season moves the maturing stage backward up to 6 weeks. A relatively stable length of the maturing stage under these increasing temperature scenarios indicates that thermal conditions for this 6 weeks period are favorable for boro rice maturing. The availability of such a long favorable thermal environment is encouraging news for Bangladeshi farmers.

\subsection{Effect of synthetically fluctuated air temperature on evapotranspiration}

Fig. 4 shows the boro rice growing season total evapotranspiration under synthetically fluctuated thermal conditions. Seasonal total evapotranspiration has increased under reduced air temperature due to a longer growing season (Fig. 5). Opposite results occur under increased air temperature conditions. The model calculates that the average seasonal total evapotranspiration increases $37 \mathrm{~mm}$ or $5 \%$ with each $1^{\circ} \mathrm{C}$ decrease of air temperature. Furthermore, seasonal total evapotranspiration decreases with increasing air temperature because of a shorter growing season. On average, seasonal evapotranspiration decreases $32 \mathrm{~mm}$ or $4 \%$ with each $1^{\circ} \mathrm{C}$ air temperature increase. 


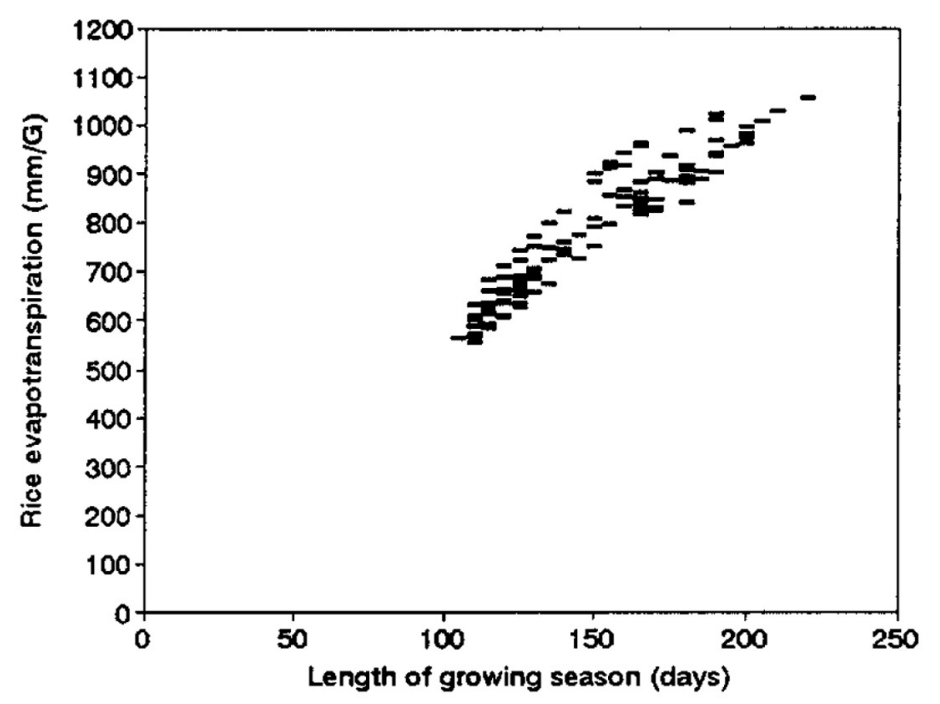

Fig. 4. Length of growing season vs. boro rice ET in Bangladesh.

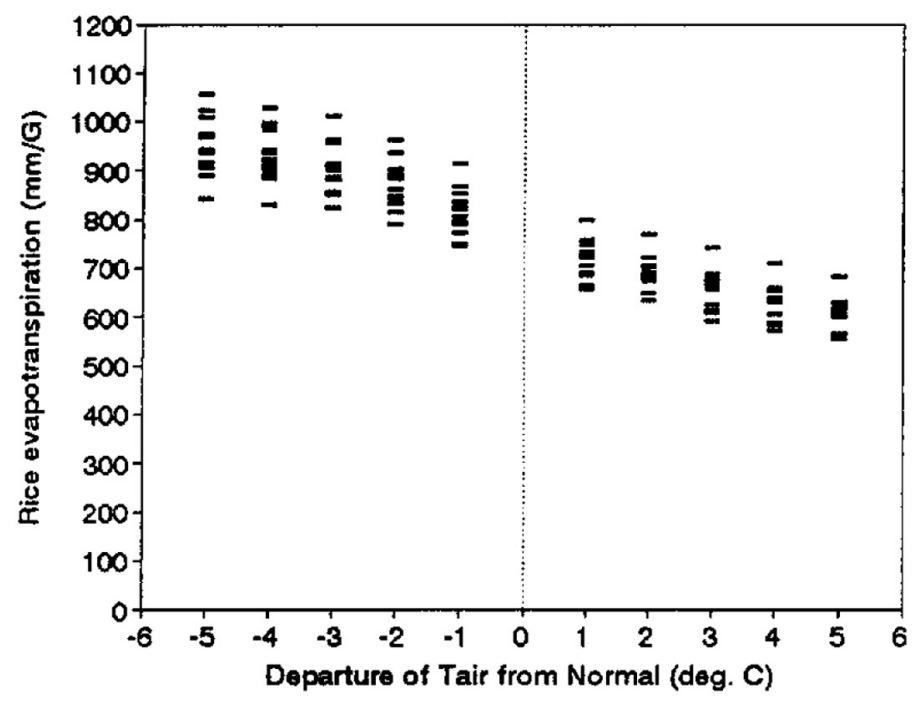

Fig. 5. Boro rice ET in Bangladesh under abnormal thermal conditions.

6.4. Impacts of variable length of growth stages on water requirements and irrigation facilities

Table 10 presents additional water requirements for boro rice growing areas under cooler climates. It is evident that irrigation water requirements will increase due to the longer growing season which results. from the below normal growing season air temperatures. In 
Table 10 Irrigation water requirements under cooler air temperature conditions

\begin{tabular}{lllllll}
\multicolumn{1}{c}{$\begin{array}{c}\text { Standard } \\
\text { climate }\end{array}$} & $-5^{\circ} \mathrm{C}$ & $-4^{\circ} \mathrm{C}$ & $-3^{\circ} \mathrm{C}$ & $-2^{\circ} \mathrm{C}$ & $-1^{\circ} \mathrm{C}$ \\
\hline Average ET for Bangladesh (mm) & 761 & 949 & 935 & 910 & 873 & 816 \\
Percent (\%) of increase in ET & 25 & 23 & 19 & 15 & 7 & $7.07 \times 10^{8}$ \\
$\begin{array}{l}\text { Volume of additional water } \\
\quad \text { requirements for Bangladesh }\left(\mathrm{m}^{3}\right)\end{array}$ & $2.42 \times 10^{9}$ & $2.23 \times 10^{9}$ & $1.92 \times 10^{9}$ & $1.44 \times 10^{9}$ & \\
\hline
\end{tabular}

Area under boro rice cultivation $=1,285,830$ ha (Choudhuri, 1988).

other words, a longer growing season means longer individual growth stages in most cases. This also means higher irrigation water requirements for each growth stage. The model estimates that the demand of water will increase up to $25 \%$ under the $T_{\text {air }}-5^{\circ} \mathrm{C}$ scenario requiring an additional $2.42 \times 10^{9} \mathrm{~m}^{3}$ of water. Table 11 presents the average percent of time required to complete individual growth stages under five different thermal conditions (average total length of growing season is 100\%). The YIELD model estimates that the percent of time required to complete growth Stage I will continue to increase through the mean $T_{\text {air }}-5^{\circ} \mathrm{C},-4^{\circ} \mathrm{C}$, and $-3^{\circ} \mathrm{C}$ conditions. The percent of time required to complete Stage 2 starts increasing from $T_{\text {air }}-3^{\circ} \mathrm{C}$ scenario and continues up to $T_{\text {air }}-1^{\circ} \mathrm{C}$ scenario. Moreover, the percent of time required to complete Stages 3 and 4 continue to decrease with increasing temperature. Doorenbos and Kassam (1979) noted that a sufficient supply of water is necessary to recover from transplanting. Thus, a longer initial stage requires that irrigation planners to reschedule irrigation. In addition, they found that evapotranspiration increases as vegetative growth (Stage 2) progresses. Evapotranspiration reaches its

Table 11 Percent time required to complete individual growth stages under below normal air temperature

\begin{tabular}{lllll}
$\begin{array}{l}\text { Deviation of } \\
\text { temperature } \\
\text { from the normal }\end{array}$ & $\begin{array}{l}\text { Initial } \\
\text { growth } \\
\text { stage (\%) }\end{array}$ & $\begin{array}{l}\text { Vegetative } \\
\text { stage } \\
(\%)\end{array}$ & $\begin{array}{l}\text { Flowering/ } \\
\text { heading } \\
\text { stage (\%) }\end{array}$ & $\begin{array}{l}\text { Maturing } \\
\text { stage } \\
(\%)\end{array}$ \\
\hline$-5^{\circ} \mathrm{C}$ & 14.00 & 35.00 & 32.00 & 19.00 \\
$-4^{\circ} \mathrm{C}$ & 19.45 & 33.65 & 30.44 & 16.25 \\
$-3^{\circ} \mathrm{C}$ & $21.2 \mathrm{O}$ & 35.00 & 28.09 & 15.71 \\
$-2^{\circ} \mathrm{C}$ & 20.00 & 37.40 & 27.40 & 15.20 \\
$-1^{\circ} \mathrm{C}$ & 15.00 & 42.00 & 28.00 & 15.00 \\
\hline
\end{tabular}

Length of the total growing season is $100 \%$ time. 
maximum shortly before the flowering to early yield formation stage (Doorenbos and Kassam, 1979). Fluctuations in the length of the Stage 2 also requires rearranging of irrigation schedule.

Rogers et al. (1989) noted that Bangladesh is using only $25 \%$ of its irrigation potential. Lack of irrigation pumps, insufficient maintenance facilities, and the high cost of energy are notable causes of failure to utilize available water resources. Increased irrigation water requirements due to a longer growing season under cooler environments will only make the current situation worse by overloading existing facilities. It has been noted earlier that there is a very high possibility of drier than present winter soil moisture conditions in Bangladesh because of $2 \times \mathrm{CO}_{2}$ induced global warming (Zhao and Kellogg, 1988; Mitchell et al., 1990). The drier conditions will increase the demand of water supply. Although it is noted that $85 \%$ of the area under boro rice cultivation receives water through irrigation, the supply of water is not optimum in many cases. Higher demands for water due to the drier and the cooler climate will increase the gap between demand and supply of water, and will reduce evapotranspiration. This, in turn, will reduce boro rice productivity (Mahmood, 1993; Mahmood and Hayes, 1995). The warmer conditions (as predicted by the GCMs) will result in shorter growing season and cause slight increase in daily evapotranspiration rate. Although daily evapotranspiration rate increases, the shorter growing season will result in the reduction of the end of the season total evapotranspiration.

\section{Conclusions}

The YIELD model has been applied to 12 major rice growing regions for ten air temperature variation scenarios. These scenarios represent cooler or warmer growing season air temperatures and possible global warming conditions. The present study estimates a non-linear relationship between decreasing air temperature and the length of the initial growth stage and a largely linear relationship with other growth stages. Under $T_{\text {air }}-5^{\circ} \mathrm{C}$ condition, the YIELD model pushes transplanting dates 2-7 weeks forward causing a relatively quick entrance of the boro rice plants into the summer season. This results in shorter initial growth stage under $T_{\text {air }}-5^{\circ} \mathrm{C}$ scenario compared with 
$T_{\text {air }}-4,-3$, and $-2^{\circ} \mathrm{C}$ scenarios. As air temperature increases from $T_{\text {air }}-5^{\circ} \mathrm{C}$ to $T_{\text {air }}-3^{\circ} \mathrm{C}$ conditions, the length of initial growth stages also increases. Increasing air temperatures push transplanting dates close to January 1 and force rice plants to grow under a cooler thermal climate. Such climate conditions require a longer time for boro rice to complete initial growth stage. This study finds that seasonal total evapotranspiration will increase up to $5 \%$ under each $1^{\circ} \mathrm{C}$ cooler than normal conditions. A rise in evapotranspiration will result in higher demands for irrigation water. These conditions will put tremendous pressure on the current irrigation facilities in Bangladesh and result in reduction of boro rice yields.

The model application shows that an increase in air temperature will provide longer and more stable thermal conditions for the boro rice maturing stage. A $4 \%$ decrease in seasonal total evapotranspiration will occur under each $1^{\circ} \mathrm{C}$ increased air temperature conditions. The warmer air temperature conditions will result in shorter growing season and reduce end of the season total evapotranspiration. Furthermore, the variations in the percent of time required for the completion of different growth stages under various air temperature conditions will require a reorganization of irrigation schedules.

Acknowledgments The author would like to thank Prof. John Hayes of the Department of Geography, Salem State College, Prof. David Legates of the Department of Geography, The University of Oklahoma, and two anonymous reviewers for their valuable comments and suggestions. Thanks also go to David Robertson for reading the manuscript and Greg Taylor for cartographic help. Figs. 1, 4 and 5 of this article have been reprinted with permission from Physical Geography, 16: 463-486 (c) V.H. Winston and Sons, Inc., 360 South Ocean Boulevard, Palm Beach, FL 33480. All rights reserved.

\section{References}

Bangladesh Rice Research Institute (BRRI), 1985. Annual Report for 1982.

Bangladesh Rice Research Institute, Dhaka, Bangladesh.

Bangladesh Rice Research Institute (BRRI), 1988. Annual Report for 1986. Bangladesh Rice Research Institute, Dhaka, Bangladesh.

Bangladesh Rice Research Institute (BRRI), 1991. Rice yield and environmental data. Bangladesh Rice Research Institute, Dhaka, Bangladesh. 
Biswas, J.K., Haque, M.Z., Miah, A.A., Nasruddin, M. and Mushi, A.A.A., 1989. Dry matter production and its relationship with yield and yield components of rice. Bangladesh Journal of Botany, 18: 117-121.

Burt, J.E., Hayes, J.T., O’Rourke, P.A., Terjung, W.H. and Todhunter, P.E., 1980. WATER: A Model of Water Requirements for Irrigated and Rainfed Agriculture. Publications in Climatology, Vol. 33, no. 3, C.W. Thornthwaite Associate and Center for Climatic Research, Elmer, NJ.

Burt, J.E., Hayes, J.T., O’Rourke, P.A., Terjung, W.H. and Todhunter, P.E., 1981. A parametric crop water use model. Water Resour. Res., 17: 1095-1108.

Choudhuri, S.I., 1988. Arthanitik Bhugol Visva o Bangladesh. University of Dhaka, Dhaka, Bangladesh.

De Datta, S.K., 1981. Principles and Practices of Rice Production. John Wiley and Sons, New York.

Dickinson, R.E., 1989. Uncertainties of estimates of climatic change: a review. Clim. Change, 15: 5-13.

Doorenbos, J. and Kassam, A.H., 1979. Yield responses to water. Irrigation and Drainage Paper, Vol. 33, Food and Agricultural Organization, Rome.

Doorenbos, J. and Pruitt, W.O., 1977. Crop water requirements. Irrigation and Drainage Paper, Vol. 24, Food and Agricultural Organization. Rome.

Food and Agricultural Organization of the United Nations (FAO), 1987. Agroclimatological Data for Asia. Vol. 1, Food and Agricultural Organization of the United Nations, Rome.

Ghan, S.J., 1992. The GCM credibility gap. Clim. Change, 21: 345-346.

Haque, M.Z., 1986. Effect of nitrogen, phosphorus and potassium on spikelet sterility induced by high temperature at heading stage of rice. Bangladesh $\mathrm{J}$. Agric., 11: 25-32.

Haque, M.Z., 1987. Effect of climatic factors on rice cropping patterns in Bangladesh. In: Weather and Rice. International Rice Research Institute, Manila, Philippines, pp. 177-187.

Hayes, J.T., 1986. Climatic change and water and yield responses for rice in California. Ph.D. Dissertation, University of California, Los Angeles.

Hayes, J.T., O’Rourke, P.A., Terjung, W.H. and Todhunter, P.E., 1982a. A feasible crop yield model for worldwide international food production. Int. J. Biometeorol., 26: 239-257.

Hayes, J.T., O’Rourke, P.A., Terjung, W.H. and Todhunter, P.E., 1982b. YIELD: A Numerical Crop Yield Model of Irrigated and Rainfed Agriculture. Publications in Climatology, Vol. 35, No.2, C.W. Thornthwaite Associates and Center for Climatic Research, Elmer, NJ.

Liverman, D.M., Terjung, W.H., Hayes, J.T. and Mearns, L.O., 1986. Climatic change and grain corn yields in the North American Great Plains. Clim. Change, 9: 327-347.

Mahmood, R., 1993. Climatic change and boro rice yield in Bangladesh: application of a parametric crop yield model. Master's Thesis, Department of Geography and Planning, State University of New York, Albany, NY. 
Mahmood, R. and Hayes, J.T., 1995. A model-based assessment of impacts of climate change on boro rice yield in Bangladesh. Phys. Geogr., 16: 463-486.

Mearns, L.O., 1982. Simulating the effect of climatic variability on wheat yields in Australia. Master's Thesis, Department of Geography, University of California, Los Angeles, CA.

Mitchell, J.F.B., Manabe, S., Tokioka, T. and Meleshko, V., 199o. Equilibrium climate change. In: J.T. Houghton, G.J. Jenkins and J.J. Ephraums (Editors), Climate Change: The IPCC Scientific Assessment. Cambridge University Press, New York, pp. 131-172.

Munakata, K., 1976. Effects of temperature and light on the reproductive growth and ripening of rice. In: Climate and Rice. The International Rice Research Institute. Manila, Philippines. pp. 187-210.

Nishiyama. I., 1976. Effects of temperature on the vegetative growth of rice plants. In: Climate and Rice. The International Rice Research Institute, Manila, Philippines, pp. 159-185.

Oldeman, L.R., Seshu, D.V. and Cady, F.B., 1987. Response of rice to weather variables. In: Weather and Rice. International Rice Research Institute, Manila, Philippines, pp. 5-39.

Parry, M., 1992. The potential effect of climate change on agriculture and land use. In: M. Begon, A.H. Fitter and A. Macfadyen (Editors), Advances in Ecological Research. Academic Press, New York, pp. 63-91.

Parry, M. and Carter, T., 1990. Some strategies of agriculture to changes of climate. In: H.-J. Karpe, D. Otten and S.C. Trinidade (Editors). Climate and Development: Climatic Change and Variability and the Resulting Social, Economic and Technological Implications. Springer-Verlag, New York, pp. $152-172$.

Parry, M.L., Carter, T.R. and Konjin, N.T., 1985. IISA/UNEP climate impacts project: the vulnerability of food production in climate-sensitive areas. Bull. Am. Meteorol. Soc., 66: 1310-1311.

Penman, H.L., (1948). Natural evaporation from open water, bare soil and grass. Proceedings of the Royal Society, Series A, 193: 120-145.

Rogers, P., Lyndon, P. and Seckler, D., 1989. Eastern waters study: strategies to manage flood and drought in the Ganges-Brahmaputra basin. United States Agency for International Development, Washington, DC.

Rosenzweig, C. and Hillel, D., 1993. Agriculture in a greenhouse world. Natl. Geogr. Res. Explor., 9: 208-221.

Rosenzweig, C. and Parry, M.L., 1994. Potential impact of climate change on world food supply. Nature, 367: 133-138.

Rudolff, W., 1981. World Climates with Tables of Climatic Data and Practical Suggestions. Wissenschaftliche Verlagsgesellschaft mbH, Stuttgart.

Terjung, W.H., Ji, H.-Y., Hayes, IT., O’Rourke, P.A. and Todhunter, P.E., 1983. Crop water requirements for rainfed and irrigated grain com in China. Agric. Water Manage., 6: 43-64. 
Terjung, W.H., Hayes, J.T., Ji, H.-Y., O’Rourke, P.A. and Todhunter, P.E., 1984 a. Crop water requirements for rainfed and irrigated rice (paddy) in China. Arch. Meteorol. Geophys. Bioclimatol., Ser. B., 34: 181-202.

Terjung, W.H., Hayes, J.T., O’Rourke, P.A. and Todhunter, P.E., 1984b. Yield response of crops to change in environment and management practices: model sensitivity analysis. I. Maize. Int. J. Biometeorol., 28: 261-278.

Terjung, W.H., Hayes, J.T., O'Rourke, P.A. and Todhunter, P.E., 1984c. Yield response of crops to changes in environment and management practices: model sensitivity analysis. II. Rice, wheat, and potato. Int. 1. Biometeorol., 28: 279-292.

Terjung, W.H., Ji, H.-Y., Hayes, J.T., O’Rourke, P.A. and Todhunter, P.E., 1984d. Actual and potential yield for rainfed and irrigated maize in China. Int. J. Biometeorol., 28: 115-135.

Terjung, W.H., Ji, H.-Y., Hayes, J.T., O'Rourke, P.A. and Todhunter, P.E., 1984 e. Crop water requirements for rainfed and irrigated wheat in China and Korea. Agric. Water Manage., 8: 411-427.

Terjung, W.H., Ji, H.-Y., Hayes, J.T., O'Rourke, P.A. and Todhunter, P.E., 1984 f. Actual and potential yield for rainfed and irrigated wheat in China. Agric. For. Meteorol., 31: 1-23.

Terjung, W.H., Liverman, D.M., Hayes, J.T. and Collaborators, 1984g. Climatic change and water requirements for grain com in the North American Great Plains. Clim. Change, 6: 193-220.

Terjung, W.H., Hayes, J.T., Ji, H.-Y., Todhunter, P.E. and O’Rourke, P.A., 1985. Potential paddy rice yields for rainfed and irrigated agriculture in China and Korea. Ann. Assoc. Am. Geogr., 75: 83-101.

Terjung, W.R, Mearns, L.O., Todhunter, P.E., Hayes, J.T. and Ji, H.-Y., 1989. Effects of monsoonal fluctuations on grain yield in China. Part II: Crop water requirements. J. Clim., 2: 19-37.

Todhunter, P.E., Mearns, L.O., Terjung, W.H., Hayes, J.T. and Ji, R-Y., 1989. Effects of monsoonal fluctuations on grain yield in China. Part I: Climatic conditions for 1961-1975. J. Clim., 2: 5-17.

Yoshida, S., 1981. Fundamentals of Rice Crop Science. The International Rice Research Institute, Manila, Philippines.

Yoshida, S., 1983. Rice. In: Symposium on Potential Productivity of Field Crops Under Different Environments. International Rice Research Institute, Manila, Philippines, pp. 103-127.

Zhao, Z.-c. and Kellogg, W.W., 1988. Sensitivity of soil moisture to doubling of carbon dioxide in climate model experiments. Part II: The Asian monsoon region. J. Clim., 1: 367-378. 